\title{
The Role of Agricultural Cooperatives in Risk Management and Impact on Farm Income: Evidence from Southern Ethiopia
}

\author{
Ashenafi Duguma Feyisa \\ Economics Department, Arba Minch Univerity, Arba Minch, Ethiopia
}

Email address:

dugumaa@yahoo.com, ashenafi.duguma@amu.edu.et

\section{To cite this article:}

Ashenafi Duguma Feyisa. The Role of Agricultural Cooperatives in Risk Management and Impact on Farm Income: Evidence from Southern Ethiopia. International Journal of Economic Behavior and Organization. Vol. 4, No. 4, 2016, pp. 28-39. doi: 10.11648/j.ijebo.20160404.11

Received: November 3, 2016; Accepted: November 30, 2016; Published: January 12, 2017

\begin{abstract}
Rural households face considerable risks related to farm business such as variability of yield and market conditions. These risks are especially important if they result in income fluctuations. One possible strategy for household is to take up low-risk activities, even if they imply lower returns. This is likely if the households are constrained with risk management instruments. Integrated Seed Sector development Ethiopia program has been intervening to reduce such suboptimal decision by organizing farmers under Agricultural Cooperatives and establishing market linkage. In this paper, Author examined the role of the intervention on risk-management behavior of farm households (manifested by crop choice) and impact on farm income in case of Southern Ethiopia. The two-step Instrumental Variable estimates confirm positive impact of agricultural cooperatives on crop choice and farm income. In attempt to identify major determinants of participation in the program, the binary probit estimates shed light on factors behind the participation decision and indicates that participation in agricultural cooperatives is strongly linked to access to the program, access to information, having contact with farm extension agents, land size, distance from main road and household size. Majority of non-participants are poor, women, and young headed households. Thus, enhancing participation of the poor, women and young headed households will have favorable impact for increasing resilience of farm households and poverty reduction.
\end{abstract}

Keywords: Cooperative, Risk-Management, Impact

\section{Introduction}

Improving the productivity, profitability, and sustainability of smallholder farming is the main pathway out of poverty [1]. However, agriculture itself, a key sector operating largely in rural areas, is an intrinsically risky industry [2, 3]. Managing the important risks with which rural communities and individual residents must deal is a continuing task that has not become much easier, in spite of development of better methods and new instruments.

Shocks arising from a risky environment such as extreme weather conditions, pests, crop diseases, illnesses, and variable market conditions constrained rural households. Farmers are typically ill-equipped to face such shocks since formal credit and insurance markets are normally missing or incomplete $[4,5]$.

In response to the shocks, they adopt a variety of strategies
[6], ex-ante 1 to shield themselves against the shocks or to mitigate ex-post 2 negative effects.

Some of the issues canvassed here include, largely ex-ante risk-coping mechanisms $[7,8]$ of rural households, such as choice of a diversified crop portfolio, growing crops displaying low correlated returns, use of less risky technologies and own production of food crops to avoid price risk and guarantee stable food supply. Such strategies possibly lead to lower return (income) and further constrain their ability to choose more risky and more profitable

\footnotetext{
${ }^{1}$ Ex-ante strategies can typically include: Diversification of income sources, choice of a diversified crop portfolio, use of less risky technologies, and own production of food crops [11].

${ }^{2}$ The ex-post strategies may include: use of savings or sales of physical assets, inter-household transfers, including informal insurance agreements within the community, switching to cheaper food items, migration or displacement of family members to look for other jobs $[12,13]$
} 
opportunities (leading to vicious circle of the problem).

Optimal risk management strategies can bifurcate with wealthier families opting for high return-risky activities, whilst poor ones may remain stuck in low return-risk portfolios $[9,10]$. Therefore, a likely outcome is that risk induced poverty traps may emerge [13]. On such occasion, policy intervention which could alter risk preference and resultant outcome may induce increased ability to choose risky opportunities with high return.

However, the rural poor often lack instruments to manage risks adequately, and so are highly vulnerable. Providing appropriate risk-management instruments and supporting the critically vulnerable is thus one key pillar in an effective and sustainable rural poverty-reduction strategy. Such provision better allows the able-bodied to engage in high risk/higher return activities and thus with good fortune to move out of poverty $[14,15]$.

The role of cooperatives in risk management

Cooperatives can play a role in risk-management and increasing able-members who can engage in high risk/higher return activities [16]. They may also play significant role improving food security and generating employment opportunities contributing for global socio-economic development and promoting growth. Bernard et al. [17] pointed out that cooperatives considerably contribute to rural poverty reduction through agricultural cost reduction, access to market and better price for outputs to their members. Specifically, agricultural cooperatives play an important role in supporting small agricultural producers and marginalized groups such as young people and women. They empower their members economically and socially and create sustainable rural employment through business models that are resilient to economic and environmental shocks [18].

Cooperatives also offer small agricultural producers opportunities and a wide range of services, including improved access to markets, natural resources, information, communications, technologies, credit, training and warehouses. They facilitate smallholder producers' participation in decision-making at all levels, support them in securing land-use rights, and negotiate better terms for engagement in contract farming and lower prices for agricultural inputs such as seeds, fertilizer and equipment [19]. It is expected that policy interventions/programs which promotes agricultural cooperatives will possibly strengthen the role of cooperatives in improving risk-management and hence livelihoods of rural poor.

It is recognized that the traditional agricultural assistance programs that concentrated on building up farmers' production capabilities are no longer sufficient to ensure sustainable income growth. There is now an increasing understanding that production support activities must be linked to market conditions and build marketing linkage among different actors 3 of the chain [19]. Cooperatives play critical role in marketing and protect members from

\footnotetext{
${ }^{3}$ The actors of marketing; include producers, consumers, primary cooperatives, retailers and wholesalers.
}

exploitation of selfish businessmen and can also play a role in reducing marketing risk [16].

The Integrated Seed Sector Development program in Ethiopia (ISSD Ethiopia) implemented under the umbrella of the Bilateral Ethiopian Netherlands Effort for Food, Income and Trade Partnership (BENEFIT Partnership). The program operates in several African counties; Ethiopia, Uganda, Ghana, Zambia, Malawi, Mali, Mozambique and Burundi which named as ISSD Africa Program. In Ethiopia, the program operates in four regions (Southern, Oromia, Amhara and Tgray regions). The program aims to improve livelihood of poor farm households by supporting groups of small holder farmers organizing under agricultural cooperatives and establishing market linkage [20].

Success of such programs in improving the livelihood of farm households, among others, depends on the extent of altering risk-management behavior of small holder farmers and resultant outcome (farm income). Exposure of rural farm households to uninsured risks-as the result of variability in demand, price volatility, natural disasters, health shocks and policy changes-has high efficiency and welfare costs for poor rural households $[21,22]$.

Most of studies on contributions of agricultural cooperatives focus on "rural employment creation"[23], "improving market access" [16, 19], "increasing agricultural productivity"; [24-26], "improving adoption rate of agricultural technology"; [27, 28], "creating value chain and improving technical efficiency"; [29, 30]. Literature in the field is limited on the role of agricultural cooperatives in riskmanagement $[16,31,32]$. The purpose of this paper is presented as examining the role of agricultural cooperatives in risk-management behavior of member farmers.

\section{Theoretical Framework}

Risk aversion has been found to be a basic characteristic of human behavior resulting in development of "survival algorithms" [33, 34]. Low income, limited access to credit, no insurance market and thin or non-existent labor markets in developing countries have restricted poor rural households to protect themselves against and manage risk. On the contrary, households with ability to cushion themselves from risk take advantage of more profitable but risky opportunity than the poor whose ability to absorb or take the risk is limited [15]. For example, variations in the price of marketed output can cause farm income to vary [3]. Fluctuations in income in turn can present an acute threat to people's livelihoods even if, on average, incomes are high enough to maintain a minimal standard of living. Occasional famines provide the most egregious examples of the consequences of risk in poor societies, but risk also generates more commonplace worries such as the consequences of a bad harvest for a family's ability to afford school fees for children, or the implications of a wage-earner's illness for the ability to provide a healthy diet for the household [35].

If a risk-averse household is not able to achieve an entirely smooth consumption path through ex-post mechanisms such 
as insurance, saving, and credit transactions [36], it has an incentive to devote resources in an effort to secure a more stable income stream. In an agricultural economy, households might farm a diversified portfolio of land [37], intercropping or choose drought-resistant crops [38, 39] and contractual arrangements such as sharecropping [34] that reduce the variance of income, or diversify their activities through migration or local non-agricultural employment [40]. Any of these ex-ante actions might be costly, so that the households would be sacrificing income, on average, in order to assure a less risky stream of income [9, 12].

In this paper, the risk aversion arguments are expanded to analyze how such behavior affected by policy intervention (market based risk-management through establishing agricultural cooperatives). Participation status in agricultural cooperative is used as a base for difference in risk aversion behavior (if any) manifested by crop choice of farm households. Participants are expected to be relatively risk takers choosing more risky and more profitable crops by allotting relatively more of their plot of land for such crops. Contrary to this, non-participants expected to be relatively risk averse choosing less risky and less profitable crops. Hence, we hypothesized in this study that non-participants who are undertaking their farm business under marketing risk make sub-optimal investment decisions. As a result, they are unwilling to undertake crop choices which are more risky but promises high profitability. This is contrary to the participants who are secured against marketing risk via their membership in agricultural cooperative who able to took advantage of more profitable but risky opportunities [15].

It is also expected that the program contributes towards wealth accumulation of participants via higher and secured crop price that leads to higher farm income compared to nonparticipants. This will further build risk taking capacity of the members. Study on correlation between wealth and crop choice by [41] shows that partial risk aversion reduced significantly as the wealth of rural household in Zambia increases.

Cash crops are riskier compared to food crops. They are at least prone to risks correlated with market conditions than food crops since they are mostly produced for selling. Study on corelation between wealth and crop choice by [34] shows that wealthier farmers choose cash crops in Tigray, the northern part of Ethiopia. In this study, we also expect that participants are wealthier than non-participants in terms of higher farm income, cash savings and livestock ownership probably due to their crop choice (cash crops).

Even though a crop choice depends on both economic and agro-ecological factors, economic factors, especially market conditions play a significant role in crop choice. Pender and Alemu [42] found that market access, price of the crop, income strategy and land management practices influence crop choices on land in East Africa Highlands. Better access to market in Kenya was driving preferences for crops choices by farmers noting that farm households close to market centers choose cash crops unlike those far from market centers who opt for food crops. Seid and Holger [43] also found that proximity to market centers influence decision of farmers on crop choice in Wollo, Amhara regional state of Ethiopia. As cited under [34], [44] also found teff production (a common cash and food crop in the northern part of Ethiopia) common than food crops in areas around urban markets. Market access was found to influence non-farm opportunity, intensification of use of fertilizer and other inputs which are consistent with better land productivity [45].

Participants of the ISSD Ethiopia program are better-off due to special treatments they received compared to their counter parts. Participants have better access to input loan, secured market and price incentive (receiving up to $15 \%$ mark-up on prevailing market price when they supply to their cooperative). The program service is not only an attempt to tackle the problem of market imperfections and high transaction costs but also play as "insurance policy" against market risk during times of market fluctuations [46]. Particularly, access to credit, secured market and price incentive may increase risk taking capacity and hence increase productivity and farm income. These in turn possibly have significant contribution for wealth accumulation and negative impact on farmers' risk aversion behavior which further build capacity for risk absorption. Under the following theoretical framework, path of influence of participation on crop choice and farm income is presented. 


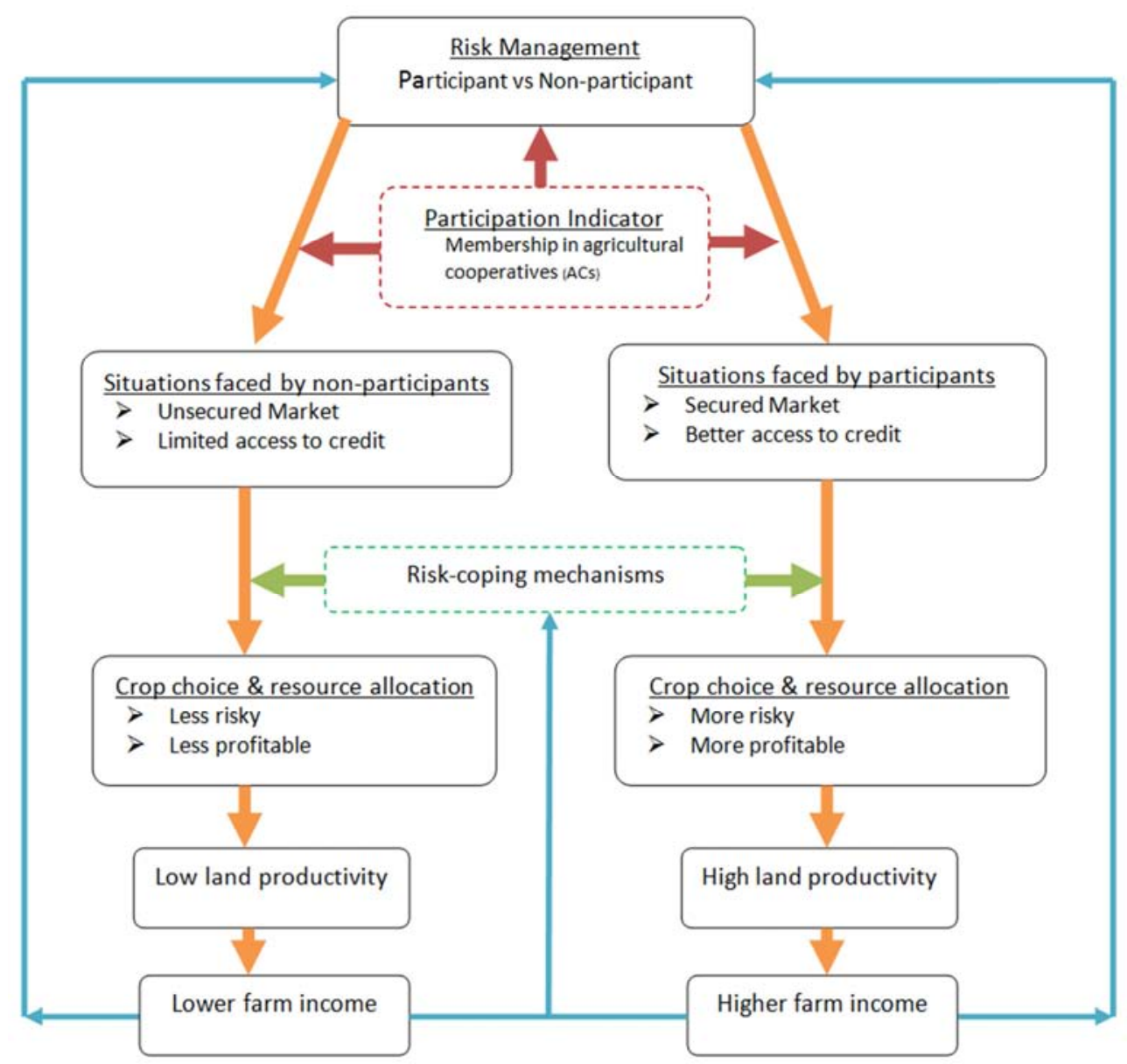

Figure 1. Theoretical framework.

\section{Data and Methods}

The paper mainly depends on primary survey data collected from Sidama and Silti zones of Southern Nations Nationalities and People's Region using structured questionnaire and focused group discussion in 2013. Multistage sampling technique followed from district selection to farm household survey. Firstly, five districts in the region where the program is being implemented were identified. From identified districts, two of them (Boricha and Lanfero districts) were randomly selected for this study. From 2057 household heads in two districts, 253 of them are members of Agricultural Cooperatives (ACs). Based on their proportion, a total of 185 sample respondents constituting both participants and non-participants were randomly surveyed from selected districts. Data collection was administered using trained enumerators.

\subsection{Econometric Model}

The models for assessing impact of the program on crop choice and farm income are based on the following premises. There are evidences that show risk handling behavior of farm households revealed in their ex-ante risk cooping strategy at household level through crop choice [47-49]. If a risk-averse household is not able to achieve smooth consumption path through ex-post mechanisms such as selling asst, insurance, saving, and credit transactions $[36,50]$, it has an incentive to devote resources in an effort to secure a more stable income stream choosing low-risk and low-return crops such as food crops [12]. However, if the households able to manage and absorb risk, they tend to devote resources for risky but high return crops. As a result, they able to exploit higher farm income opportunities. Based on the above premises, we have developed two models; crop choice and farm income that presented in the following sections.

\subsubsection{Impact of Participation on Crop Choice}

In order to quantify the relation between participation and risk preference manifested by crop choice, the following econometric model has developed.

$$
L_{i}^{c}=\beta_{0}+\alpha_{1} w+\beta_{i} \boldsymbol{x}_{i}+u_{i}
$$

In the above crop choice mode, the dependent variable is proportion of land allotted to cash crops out of total farm land $\left(L^{c}\right)$. The variable assumes the maximum value 1 if the households allotted all of its land for cash crop and the minimum value 0 if nothing is allotted for such crop (i.e. $0 \leq$ $\left.L^{c} \leq 1\right)$. Though the interest variable in determining risk taking behavior is participation status $(w)$ in this paper, other set of 
variables also expected to affect risk preference (crop choice). These are vector of explanatory variables $\left(\boldsymbol{x}_{i}\right)$ which includes age of the household head, literacy status of the household head, household size, distance from main road, cash savings, access to credit, access to farm extension agent, land endowment and livestock ownership. In the specified model, $\beta_{0}, \alpha_{1}$ and $\beta_{i}$ are parameters and $u_{i}$ is an error term.

\subsubsection{Impact of Participation on Farm Income}

To investigate whether participation predicts farm income, we used annual per capita farm income $\left(Y_{i}\right)$ in Birr as dependent variable. We included treatment variable participation $(\mathrm{w})$ and other covariates $\left(\mathrm{x}_{\mathrm{i}}\right)$ such as household characteristics (age, sex and literacy of household head), assets of the households (land and livestock) and crop choice (proportion of land allotted to cash crops out of total land holding) as presented on the following equation (2).

$$
Y_{i}=\beta_{0}+\alpha_{1} w+\beta_{i} x_{i}+u_{i}
$$

Where, $\beta_{0}, \alpha_{1}$ and $\beta_{i}$ are parameters and $u_{i}$ is an error term.

\subsection{Analytical and Estimation Technique}

Most approaches to estimate treatment effects fall in to one of the following approaches. The first approach is based on Ignorability Assumption or unconfoundedness of treatment conditional on a set of observed covariates. In fact one approach to estimate treatment effect is to use linear regression with many controls: in effect, the treatment is exogenous once we control for enough observed factors. Important benefit of ignorability of treatment is that no functional form or distributional assumptions are needed to identify population parameters of interest [51].

A second approach allows selection in to treatment to depend on unobserved (and observed) factors. Traditionally, we would say that treatment is "endogenous". In this case we rely on the availability of Instrumental Variables (IVs) in order to identify and estimate Average Treatment Effects (ATEs). Randomized treatment guarantees that difference-inmeans estimator from basic statistics is unbiased, consistent and asymptotically normal. But the problem is that randomization of treatment is often infeasible in program/program evaluation (although randomization of eligibility sometimes is feasible). In most cases, individuals at least partly determine whether they receive treatment, and their decision may be related to the benefits of or gain from treatment, $\mathrm{y}_{1}-\mathrm{y}_{0}$ (where $\mathrm{y}_{1}$ outcome after participation and $\mathrm{y}_{0}$ is outcome without participation). In other words, there is self-selection into treatment [52].

The participation/membership in cooperatives supported by ISSD program was mainly based on the willingness of the households. This indicates there was self-selection into treatment. To evaluate impact of the program, methods such as difference in difference (DID), propensity score matching and instrumental variable (IV) are competing methods. However, the interest variable, participation, is suspected to be endogenous at least for the reason of self selection.
Instrumental-variables (IV) estimation solves this problem by restoring contingency under the hypothesis of selection on unobservable. Nevertheless, the application of IV requires the availability of at least one variable $z$, called "instrumental variable", assumed to have the following two properties:

1. $z$ is (directly) correlated with participation/treatment $w$

2. $z$ is (directly) uncorrelated with outcome $y$.

This implies that the selection into program depends on the same factors affecting the outcome plus instrument $z$ that does not affect directly the outcome (but only indirectly via its effect on $w$ ). This is the basic exclusion restriction under which IV is able to identify casual parameters. In this paper, the binary variable denoting the household's "access to agricultural cooperatives" is taken as a "natural" instrument for the participation status variable (which is the treatment variable here). However, firstly one cannot participate without having access to the program deliverables. Secondly, it is natural to assume that access to the program affects the overall household welfare outcome indicators such as increase in farm income only through participation (i.e. the mere having access to participation without being beneficiary does not affect the welfare outcome indicators of the households). Hence, the two requirements for the access to program status variable $(z)$ to be a valid instrument for the participation status variable $(w)$ are met.

Considering the switching random coefficient model: $y=$ $\mu_{0}+w\left(\mu_{1}-\mu_{0}\right)+v_{0}+w\left(v_{1}-v_{0}\right)$, where $y$ stands for outcome variable (crop choice or farm income), $\left(\mu_{1}-\mu_{0}\right)$ difference in means of outcome with participation and without participation, $w$ stands for participation, $\left(v_{1}-v_{0}\right)$ difference in means of error with participation and without participation and $v_{0} \& \mu_{0}$ are constant terms. When participation in the program is not random, the conditional mean independence hypothesis will not hold.

Then we will have that $\mathrm{E}\left(v_{1} \mid w, \mathrm{x}\right) \neq \mathrm{E}\left(v_{1} \mid \mathrm{x}\right)$ and $\mathrm{E}\left(v_{0} \mid w\right.$, $\mathrm{x}) \neq \mathrm{E}\left(v_{0} \mid \mathrm{x}\right)$. We can distinguish these two cases. Firstly, $v_{l}=$ $v_{0}$ (homogenous impact) and $v_{1} \neq v_{0}$ (heterogeneous impact). In case one where $v_{1}=v_{0}$, so that $y=\mu_{0}+w\left(\mu_{1}-\mu_{0}\right)+v_{0}$ implying that Average Treatment Effect (ATE) equals Average Treatment Effect on Treated (ATET) and this is equals with Average Treatment Effect on Not Treated $(\mathrm{ATENT}) ; \mathrm{ATE}=\mathrm{ATET}=\mathrm{ATENT}=\mu_{1}-\mu_{0}$. Otherwise all of them will be different (the second case). In this paper, the first case expected to holds true because except, based on participation status, impact of the program was not significantly vary based on other attributes of the sample households.

Suppose access to program status variable $z$ (instrumental variable) having these two properties:

a $\mathrm{E}\left(\mathrm{v}_{0} \mid \mathbf{x}, \mathrm{z}\right)=\mathrm{E}\left(\mathrm{v}_{0} \mid \mathbf{x}\right)<=>\mathrm{z}$ is uncorrelated with $\mathrm{v}_{0}$ Exclusion restriction of instrumental variable $\mathrm{z}$ from the outcome model

b $\mathrm{E}(\mathrm{w} \mid \mathbf{x}, \mathrm{z}) \neq \mathrm{E}(\mathrm{w} \mid \mathbf{x})<=>\mathrm{z}$ is correlated with $\mathrm{w}$ Inclusion restriction of instrumental variable $\mathrm{z}$ in the selection model

Taking (a), we assume that: $\mathrm{E}\left(v_{0} \mid \mathbf{x}, z\right)=\mathrm{E}\left(v_{0} \mid \mathbf{x}\right)=\mathrm{g}(\mathbf{x})=$ $\beta_{i} \boldsymbol{x}_{i}$ meaning that $\mathrm{E}\left(v_{0} \mid \mathbf{x}, z\right) \neq 0$.

After simple manipulations, we get a regression model 
having an error term with zero unconditional mean of this type:

$$
\mathrm{y}=\mu_{0}+\mathrm{wATE}+\beta_{i} \boldsymbol{x}_{i}+\mathrm{u}_{0}
$$

That is a regression model in which $(\mathbf{x}, z)$ are uncorrelated with the error term $u_{0}$ (i.e., $(\mathbf{x}, z)$ are exogenous) but the error term $u_{0}$ is correlated with $w$. These conditions bring to the following

Structural System of (two) Equations:

i. $\mathrm{Y}_{\mathrm{i}}=\mu+\mathrm{w}$ ATE $+\beta_{i} x_{i}+u_{i}$ outcome equation

ii. $\quad \mathrm{W}_{\mathrm{i}}^{*}=\partial_{\mathrm{o}}+\partial_{\mathrm{i}} \mathrm{D}_{\mathrm{i}}+\mathrm{e}_{\mathrm{i}}$ selection equation

Where, in the outcome equation $Y i$ stands either for crop choice or farm income of sample households, $w$ stands for participation (treatment), ATE is Average Treatment Effect (coefficient of $w$ ), $\mathrm{x}_{\mathrm{i}}$ is vector of other explanatory variables where as $\mu \& u_{i}$ are constant and random terms respectively. In the selection equation, $W_{i}^{*}$ stands for participation in ISSD supported farm cooperatives, $D_{i}$ vector of explanatory variables, $\partial_{o} \& e_{i}$ are constant and random terms respectively and $\partial_{i}$ is vector of coefficients. The IV estimation that follows Probit-2SLS steps is applied for evaluating impact of participation on crop choice and farm income.

This technique first it applies a Probit of participation (w) on $D_{i}\left(\mathrm{x}_{\mathrm{i}}\right.$ and $\left.z\right)$, getting the "predicted probability of $w$ ", and then it uses these probabilities by applying a 2SLS with predicted probabilities as instrument for $w$. Hence, $w$ identifies impact of the program on crop choice and farm income.

\section{Results and Discussion}

\subsection{Characteristics of Sampled Households}

Majority (90\%) of surveyed households are male headed. This was expected because in Ethiopia households are mostly headed by male unless a woman is divorced or widowed. Average family size of 12 members among non-participating households is relatively higher than that of their counterparts which stood at 10 as presented in table 1 . The figures of both groups are higher than the regional average of 7 . Polygamous marriage is very common in the selected research site and hence this could be a possible reason for higher average family size compared to the regional average. The mean education level among participants is relatively higher (4 years) than that of non-participants (1.6 years).

Table 1. Summary Statistics of Socio-Economic Variable by Participation Status.

\begin{tabular}{|c|c|c|c|c|}
\hline Demographic and socio-economic variables & Participant & Non-participant & Mean difference $\left(\mathrm{Px}_{\mathrm{i}}-\mathrm{NPx}_{\mathrm{i}}\right)$ & P-value \\
\hline Age of HH head (in years) & 42.7 & 37.8 & 4.9 & 0.0006 \\
\hline Education of HH head (in years) & 4 & 1.6 & 2.4 & 0.0000 \\
\hline Household size (number of family members) & 10 & 12 & -2 & 0.0214 \\
\hline Land size (in hectare) & 2.4 & 1.1 & 1.3 & 0.0000 \\
\hline Rented land size (in hectare) & 0.5 & 0.3 & 0.2 & 0.0309 \\
\hline Distance from main road (in $\mathrm{km}$ ) & 2.1 & 6.2 & -4.1 & 0.0000 \\
\hline Average yearly farm income (in Birr) & 38,651 & 16,702 & 21949 & 0.0000 \\
\hline \multicolumn{5}{|l|}{ Risk preference } \\
\hline Share of land allotted to cash crops & 0.55 & 0.26 & 0.29 & 0.0000 \\
\hline Share of land allotted to food crops & 0.4 & 0.7 & -0.3 & 0.0001 \\
\hline Number of type of crops grown & 3.5 & 5.3 & -1.8 & 0.0000 \\
\hline \multicolumn{5}{|l|}{ Wealth } \\
\hline Number of oxen & 2.7 & 1.2 & 1.5 & 0.0001 \\
\hline Livestock (in TLU) & 6.9 & 3.8 & 3.1 & 0.0002 \\
\hline Average yearly cash saving (in Birr) & 3,235 & 542 & 2693 & 0.0001 \\
\hline
\end{tabular}

Note: $\mathrm{Px}_{\mathrm{i}}$ and $\mathrm{NPx}_{\mathrm{i}}$ are mean values of variables included in this table for participants and non-participants respectively.

The sample survey result presented in table 1 reveals difference in risk preference and management between the two groups. For example, average proportion of land allotted to cash crops is higher (55\%) among participants while it is relatively lower $(26 \%)$ among non-participants. In addition, participants on average grow 3 types of major crops on their plot of land; however, non-participants grow on average 5 types of crops. The cultivation of diverse crops, mainly food crops, on relatively small plot of land by non-participants implies their attempt to manage risk by undertaking crop diversification as an ex-ante strategy. However, such strategy leads to land fragmentation and perhaps for lower land productivity and lower farm income.

The result also shows viable variation of wealth among members and non-members of agricultural cooperatives. In this paper; yearly cash saving, number of oxen and other livestock are used as a proxy for wealth. In the study area, number of oxen and other livestock considered as indictor for wealth of farm households. Oxen also used as traction power during crop production. Cash savings are used for investment on agricultural inputs which could enhance land productivity and farm income. Participants are relatively wealthier than non-participants averagely owning 2.8 hectares of land and 3 oxen while the non-participants own only 1.1 hectares of land and 1 ox. Average yearly saving among non-participants is only Birr 542; however, it stood at Birr 3,235 for participants. Furthermore, livestock ownership of participants is 6.9 in Tropical Livestock Unit but it is 3.8 for those outside the cooperative.

Perhaps the difference on wealth among the two groups is an outcome of difference on risk preference and management strategy resulted from program intervention. But, causal 
relationship between participation, risk preference (crop choice) and farm income will be empirically tested in the following sections.

\subsection{Econometric Result}

\subsubsection{Impact of Participation on Crop Choice}

The crop choice model indicates statistically significant impact of participation on crop choice (see table 2). It is believed that two factor played a role for such causal relationship between participation and crop choice. The first reason could be the special treatment they obtained from the program in terms of secured market and access to credit. This might have motivated them to allot more of their land for cash crops, which are relatively riskier than food crops. Cash crops are at least prone to demand and crop price fluctuation which will make risk-aversive households reluctant to choose the crops.

On one hand, secured market may motivate at least riskaversive households serving as insurance against demand and price fluctuation. The program beneficiaries directly supply their produce to cooperatives receive price mark-up which can goes up to $15 \%$ higher compared to prevailing market price. The result of this paper supports the findings of [44] who found teff production (a common cash and food crop in the northern part of Ethiopia) common than food crops in areas around urban markets. Market access was also found to influence non-farm opportunity, intensification of use of fertilizer and other inputs which are consistent with better land productivity [45].

On the other hand, having access to credit probably increased their confidence to choose risky crops since it is one of ex-post strategies to manage risk. The result presented in table 2 confirms statistically significant effect of having access to credit on determining crop choice which is in line with the finding of [36].

The second reason could be accumulated wealth through higher farm income. In this paper, annual cash savings and livestock are used as a proxy for wealth/asset base of the sampled households. As it was identified under section 4.1 of this paper, participants are relatively wealthier than their counterparts. As a result, there will be higher probability of insuring their income source through their wealth compared to non-participants that could possibly reflected in their risk management. The finding supports result found by [53]. According to him, poor households respond to risks by making sub-optimal investment decisions which limit them from exploiting investment choices promising high expected rate of return which would have positive contribution for increased wealth. Dercon S. [32] also argues;

"Income risk reduction often comes at a cost. Income skewing is likely if less protection is available through assets. The long-term consequences for the asset-poor are lower average incomes and a higher income gap relative to assetrich households."

With a small asset base, people face difficulties in dealing with shocks and coping with risk and uncertainty. Ability of farm households to protect themselves from risk enables them to take advantage of profitable but risky opportunities unlike the poor whose choices are limited to low-risk and low-return opportunities to secure themselves from risk. Eswaran and Kotwal [15] found that rich farmers were exhibiting low risk aversion in their investment and production activities unlike poor farmers who exhibited higher levels of risk-aversion. The finding of this paper is also consistent with relative risk aversion assumptions implying that as farm households become wealthier their risk taking behavior increases [54].

Whether or not risk aversion matters much, better decisions in the risky world can usually be made if additional information that reduces uncertainty is available. Investments of time and money in collecting information about marketing opportunities and market trends can have substantial payoffs in agriculture [46]. Proximity to main road brings an advantage for increased access to market related information and reduced transaction cost, however, as the household become distant from main road it raise transaction cost and limits access to information. This could be a reason for opposite relationship between distance from main road and cash crop choice. The finding of this paper is in line with that of [43] who found opposite relationship between distance from main road and choice of risky crops in Northern Hilands of Amhara Region, Ethiopia.

Table 2. Treatment-effects model: two-step IV estimates.

\begin{tabular}{|c|c|c|c|}
\hline & & & Number of obs. $=185$ \\
\hline & & & Wald chi2(13) $=339.97$ \\
\hline \multicolumn{3}{|c|}{ Dependent variable: Share of land allotted to cash crop } & Prob $>$ chi $2=0.0000$ \\
\hline \multirow{12}{*}{ Outcome model } & Covariates & Coefficient & Standard error \\
\hline & Age of household head (in years) & $-0.0024245^{* *}$ & $(0.0011479)$ \\
\hline & Household size (Number of family members) & 0.0033894 & $(0.0025421)$ \\
\hline & Distance from main road $(\mathrm{Km})$ & $-0.065203 * *$ & $(0.0242725)$ \\
\hline & Amount of cash savings (logs) & $0.0333219 * * *$ & $(0.0077542)$ \\
\hline & Livestock ownership (TLU) & $0.0111551 * * *$ & $(0.0028534)$ \\
\hline & Access to credit $(1=$ Yes, $0=$ No $)$ & $0.0697771 * *$ & $(0.0281117)$ \\
\hline & Literacy $(1=$ literate, $0=$ illiterate $)$ & $0.1080772 * * *$ & $(0.0201767)$ \\
\hline & Amount of land (hectare) & -0.009333 & $(0.0109619)$ \\
\hline & Access to farm extension agent $(1=$ Yes, $0=$ No $)$ & $0.1173587 * * *$ & $(0.0262949)$ \\
\hline & Participation $(1=$ participant, $0=$ non-participant $)$ & $0.1258461 * *$ & $(0.0430409)$ \\
\hline & Intercept & 0.01672 & $(0.0695396)$ \\
\hline \multicolumn{4}{|c|}{ Dependent variable: Participation in agricultural cooperative } \\
\hline
\end{tabular}




\begin{tabular}{|c|c|c|c|}
\hline & & & Number of obs. $=185$ \\
\hline & & & Wald chi2 $(13)=339.97$ \\
\hline \multicolumn{3}{|c|}{ Dependent variable: Share of land allotted to cash crop } & Prob $>$ chi $2=0.0000$ \\
\hline \multirow{8}{*}{ Selection model } & Sex of household head ( $1=$ Male, $0=$ Female $)$ & $2.487315^{* * *}$ & $(0.8372027)$ \\
\hline & Age of household head (years) & $0.081603 * *$ & $(0.0263815)$ \\
\hline & Household size (number) & $-0.1068583^{* *}$ & $(0.0431929)$ \\
\hline & Access to information (Phone/Radio) & $1.527416^{* * *}$ & $(0.4603001)$ \\
\hline & Literacy $(1=$ literate, $0=$ illiterate $)$ & 0.3891352 & $(0.3486711)$ \\
\hline & Amount of land (hectare) & $0.8403253^{* * *}$ & $(0.1917530)$ \\
\hline & Access to participation $(1=$ Yes, $0=$ No $)$ & $1.039347 * *$ & $(0.3480192)$ \\
\hline & Intercept & $-5.592944 * * *$ & $(1.2088690)$ \\
\hline \multicolumn{4}{|l|}{ Hazard } \\
\hline & Lambda & $-0.0471395 * *$ & $(0.0228544)$ \\
\hline & rho & -0.49194 & \\
\hline
\end{tabular}

Legend: ${ }^{*} \mathrm{p}<.1 ; * * \mathrm{p}<.05 ; * * * \mathrm{p}<.001$

In the selection model under table 2, first stage of IV estimation, except literacy all included variables (sex of household head, age of household head, household size, access to information, land endowment and access to participation) significantly determined participation decision.

Having access to participation in farm cooperatives is precondition for actual participation. As a result, it is not surprising to see significant direct influence of the covariate on actual participation decision. On the other hand, focus group discussants mentioned that their interest to participate and having their own plot of land were also the basic precondition for being accepted as a member of farm cooperative. The result in table 2 confirms the case revealing significant direct effect of land size on participation decision. The response of discussants reveals two things. Firstly, it supports why land size positively affect participation decision and secondly it shows an evidence for existence of self-selection in to treatment which would have been a problem if it was left uncontrolled by applying IVestimation.

Being male has significant positive effect on participation. One possible reason is that in Ethiopia male heeded households have relatively greater plot of land which is the basic means of farm production and was precondition for membership in farm cooperative. The other reason could be male headed household domination in our sample as it is described in section 4.1.1 of this paper due to cultural set-up of the rural community.

Households who have access to information were expected to have better awareness about agricultural cooperatives motivating them to participate. Our result confirms that having access to Phone/Radio has significant positive effect on participation decision which are main sources of information in selected research area.

Unlike previous factors determining participation, household size has negative effect on participation decision. Evidences [55, 56] show that in developing country, large household size is correlated with poverty. When the households are poor, they tend to be reluctant to participate and choose risky crops (cash crops) and hence probably a reason for opposite relationship between participation in cash crop production and household size.

To sum up, sex of household head, age of household head, household size, access to participation (existence of SPC in respective district), access to information and land endowment are major determinants of participation in agricultural cooperatives from the first step of IV estimate (selection model).

Test statistics on the correlation coefficients of residuals (rho) of the selection and outcome models supports existence of endogeneity problem. If participation was not instrumented, ATE estimator of participation would have been biased. However, the problem is controlled by applying two-step treatment-effect model.

\subsubsection{Impact of Participation on Farm Income}

To investigate whether participation predicts farm income (particularly from cash crop production) we used annual per capita farm income in Birr as dependent variable. We included treatment variable (participation which is instrumented for self-selection bias), household characteristics (age, sex and literacy of household head) assets of the households (land and livestock) and crop choice (proportion of land allotted to cash crops out of total land holding) as explanatory variables. Apart from its direct impact on farm income, we included crop choice variable in the model to capture indirect impact of participation on per capita farm income via its effect on risk-response of the participants. Results are summarized in Table 3.

Table 3. Treatment-effects model: two-step IV estimates.

\begin{tabular}{|c|c|c|c|}
\hline & & & Number of obs. $=185$ \\
\hline & & & Wald chi2 $(12)=246.37$ \\
\hline Dependent vari & er capita farm income in Birr & & Prob $>$ chi $2=0.0000$ \\
\hline \multirow{3}{*}{ Outcome model } & Covariates & Coefficient & Standard error \\
\hline & Age of household head (in years) & $-281.8917 * * *$ & $(65.11284)$ \\
\hline & Squared age of household head & $2.369715^{* *}$ & $(0.752252)$ \\
\hline
\end{tabular}




\begin{tabular}{|c|c|c|c|}
\hline & & & Number of obs. $=185$ \\
\hline & & & Wald chi2 $(12)=246.37$ \\
\hline \multicolumn{3}{|c|}{ Dependent variable: per capita farm income in Birr } & Prob $>$ chi $2=0.0000$ \\
\hline & Sex of household head $(1=$ Male, $0=$ Female $)$ & $932.4081 * *$ & $(345.1360)$ \\
\hline & Literacy $(1=$ literate, $0=$ illiterate $)$ & $-439.9923 * *$ & $(221.1565)$ \\
\hline & Livestock ownership (in TLU) & 46.63805 & $(32.55275)$ \\
\hline & Amount of land (in hectare) & $196.163 *$ & $(109.6219)$ \\
\hline & Distance from main road (in $\mathrm{Km}$ ) & $-607.2869 * *$ & $(258.4116)$ \\
\hline & Proportion of land allotted to cash crop & $2362.621 * *$ & $(740.6354)$ \\
\hline & Participation $(1=$ participant, $0=$ non-participant $)$ & $2095.31 * * *$ & $(434.5765)$ \\
\hline & Intercept & $7053.362 * * *$ & $(1448.442)$ \\
\hline \multicolumn{4}{|c|}{ Dependent variable: Participation in agricultural cooperative } \\
\hline & Access to participation $(1=$ Yes, $0=$ No $)$ & 0.6342598 & $(0.3355371)$ \\
\hline & Sex of household head ( $1=$ Male, $0=$ Female $)$ & $2.287047 * * *$ & $(0.5716536)$ \\
\hline & Age of household head (in years) & $-0-.2405976^{* *}$ & $(0.1227983)$ \\
\hline & Squared age of household head & 0.0039294 & $(0.0015279)$ \\
\hline \multirow[t]{5}{*}{ Selection model } & Household size (Number of family members) & $-0.1022604 * *$ & $(0.0407732)$ \\
\hline & Literacy $(1=$ literate, $0=$ illiterate $)$ & 0.2371598 & $(0.2810584)$ \\
\hline & Access to information (having Phone/Radio) $(1=$ Yes, $0=$ No) & $1.682277^{* * *}$ & $(0.3363402)$ \\
\hline & Amount of land (in hectare) & $0.8408492 * * *$ & $(0.1722912)$ \\
\hline & Intercept & 0.6763097 & $(2.439029)$ \\
\hline \multicolumn{4}{|l|}{ Hazard } \\
\hline & _Lambda & $--1180.424 * * *$ & 229.4883 \\
\hline & rho & -0.90929 & \\
\hline & sigma & 1298.1813 & \\
\hline
\end{tabular}

Legend: ${ }^{*} \mathrm{p}<.1 ; * * \mathrm{p}<.05 ; * * * \mathrm{p}<.01$

The estimates reveal that the coefficients for participation and crop choice are significant in determining farm income in the study area. More importantly, proportion of land allotted to cash crop is found to significantly predict the level of per capita income of the households. These show that, other things being equal, households who allotted more of their plot of land for more risky and more profitable crops (cash crop) tend to have higher per capita farm income compared to those households who choose less risky and less profitable crops (food crops).

The major factor that contributed for difference in crop choice among sampled households is their status of participation in farm cooperative. We identified that participants of farm cooperative allotted relatively more of their plot of land to cash crops than non-participants. The result of this paper supports findings of [36]. According to them, "if a risk-averse household is not able to achieve an entirely smooth consumption path through ex-post mechanisms such as insurance, saving, and credit transactions, it has an incentive to devote resources in an effort to secure a more stable income stream". This is contrary to the participants who are secured against marketing risk and having access to credit via their membership in agricultural cooperative. Hence, they able to took advantage of more profitable but risky opportunities [15].

In addition, non-participants practice diversified crop cultivation in contrast to participants cultivating more than 5 types of crops on highly fragmented land and prefer less risky opportunities even though those opportunities yield lower returns. Studies show that many diversification or income skewing strategies are actually mean income reducing $[37,57]$. These can also be a reason for relatively lower per capita farm income. The differences in risk preference and farm income between the two groups significantly vary as a result of their participation status in agricultural cooperative.

In general, from the above analysis it is found that farm households outside the program are more likely to be risk averse than their counterparts. In addition, Women, older, illiterate and poor headed household are more likely to be risk averse than their counterparts. As a result, they prefer less risky opportunities even though those opportunities yield lower returns.

\section{Conclusion}

This paper has tried to evaluate the role of agricultural cooperatives, established and supported by ISSD Ethiopia program, in risk management and farm income. The program supports member farm households providing input loan, strengthening market linkage and price incentive that ranges up to $15 \%$ on prevailing market price. The finding if this paper shows that the program intervention affected risk preference of the members in two ways. Firstly, it cushions the members from market related risk and motivates participants to choose more risky and more profitable crops (cash crops). Secondly, the cooperative services have increased productivity and farm income of the members which builds asset base/wealth of the participants. This perhaps increased risk taking capacity of the members. As a result, significant variation in crop choice and farm income between beneficiary and non-beneficiaries of the program has confirmed implying the intervention has brought difference in risk preference. In other words, it has enabled the members to exploit risky but high return opportunities compared to their counter parts.

Among others, market uncertainty faced by farm 
households in the study area was major limiting factor to invest on risky but more profitable opportunities. Hence, established market linkage via agricultural cooperatives enabled participants to take risky opportunities and enjoy higher profit from those opportunities.

From auxiliary probit regression of participation on some explanatory variables, selection model of IV estimation, it was found that access to participation, access to media (Phone \& Radio) and contact with extension agents have significant positive relation with participation decision whereas distance from main road and household size have opposite effect on participation decision. It is inferred from the study that, majority of non-participants was relatively risk-averse choosing mainly food crops and most of them were poor, women, and young headed households.

It can be concluded that, increasing access to cooperatives via organizing pool of farmers at district level, reducing knowledge gap by providing short term trainings on adoption of improved agricultural technology and enhancing their involvement in created market linkage will have effect of reducing risk aversion behavior. In addition, improving proximity to main road by constructing rural roads which connect rural villages with urban centers will have wealth enhancing effect by reducing transaction cost and increasing incentive to produce marketable surplus. Likewise, strengthening the link between farm extension agent and farmers, creating awareness on the importance of membership in cooperatives via phone and radio possibly increase choice of risky opportunity with better return and hence better welfare. Moreover, interventions which focused on women and young headed poor households will have relatively higher welfare enhancing effect compared to their counterparts. Thus, agricultural cooperatives can play positive role in risk management and can have positive impact on risk preference and farm income.

However, care must be taken in interpreting the results as cooperative participants are small in number and the study did not included program interventions in other regions of the country. Conducting the survey at larger scale may be relevant to develop the complete picture on the contributions of agricultural cooperatives for farm households' welfare in Ethiopia. Since such types of studies are limited, it is difficult to have a benchmark to compare the welfare effect of participation. Yet, the findings of this paper may serve as a reference for similar studies in the future.

\section{Acknowledgements}

I wish to acknowledge, without implicating them in residual shortcomings, Miet Maertens and Seid Nuru for their valuable comments and suggestions.

\section{References}

[1] Bekele, S. (2010). "Agricultural Technology Adoption and Rural Poverty.” Nairobi, Keniya: CIMMYT.

[2] Fleisher, B. (1990), "Agricultural Risk Management",
Boulder, Lynne Rienner Publishers.

[3] Anderson J. R. and J. L. Dillon, (1992) "Risk analysis in dryland farming systems", Farm Systems Management Series 2, FAO, Rome (1992).

[4] R. M. Townsend, R. A. E. Mueller, (1998), "Mechanism design and village economies: from credit to tenancy to cropping groups" Review of Economic Dynamics, pp. 119172.

[5] Udry, C. (1999). "Development Microeconomics". New York: Oxford University Press Inc.

[6] Glewwe, P. and G. Hall, (1998) “Are some groups more vulnerable to macroeconomic shocks than others? Hypothesis tests based on panel data from Peru", Journal of Development Economics, vol.56, 181-206.

[7] Baez, J., Kronick, D. and Mason A. 2013 "Rural Households in a Changing Climate," World Bank Research Observer, World Bank Group, 28 (2): 267-289.

[8] Baez J., (2006): "Income Volatility, Risk-Coping Behavior and Consumption Smoothing Mechanisms in Developing Countries: A Survey," Revista Desarrolloy Sociedad, Universidad de los Andes.

[9] Rosenzweig, M. and K. Wolpin, (1993), "Credit Market Constraints, Consumption Smoothing, and the Accumulation of Durable Production Assets in Low-income Countries: Investment in Bullocks in India", Journal of Political Economy, 101, no. 2, 223-244.

[10] Dercon S. 1996: "Risk, crop choice and savings: Evidence from Tanzania," Economic Development and Cultural Change, Vol.44, No. 3, pp. 485-514.

[11] Dercon, S. and L. Christiaensen (2007), "Consumption risk, technology adoption and poverty traps: evidence from Ethiopia," The Centre for the Study of African Economies Working Paper Series, 2007, p. 265.

[12] Fafchamps, M. (1992) "Cash crop production, food price volatility, and rural market integration in the third world". American Journal of Agricultural Economics, 74 (1): 90\{99\}.

[13] Zimmerman, F. and Carter, M. (2003): "Asset Smoothing, Consumption Smoothing and the Reproduction of Inequality under Risk and Subsistence Constraints"' Journal of Development Economics, 71: 233-260.

[14] Anderson J. R, (2003), "Risk in rural development: challenges for managers and policy makers", Agricultural Systems, 75 (23), 161-197. doi: 10.1016/S0308-521X (02) 00064-1.

[15] Eswaran, M. and Kotwal A. (1990) Implications of Credit Constraints for Risk Behavior in Less Developed Economies. Oxford Economic Papers 42 (2): 473-82.

[16] Ethan L. (2009) "Risk Management in the Cooperative Contract", American Journal of Agricultural Economics. 91, No. 5 (2009): 1211-1217.

[17] Bernard, T. et al (2010). Cooperatives for Staple Crop Marketing: Evidence from Ethiopia. International Food Policy Research Institute. Washington.

[18] FAO, (2015): Agricultural cooperatives: paving the way for food security and rural development, Available from: http://www.fao.org/docrep/016/ap431e/ap431e.pdf. 
[19] FAO (2007). Approaches to linking producers to markets, Rome, FAO.

[20] ISSD. (2013). "Annual Report on the Performance of ISSD Ethiopia program, Hawassa University Section.” Hawassa: ISSD Ethiopia.

[21] Karlan, E.(2011). "Crop Price Indemnified Loans for Farmers:A Pilot Experment in Rural Ghana."The Journal of Risk and Insurance, Vol. 78, No.1, 37-55.

[22] World Bank WB (2010), Publications; Agriculture and poverty reduction.

[23] John Bryden, and Ray Bollman (1999). Rural employment in industrialized countries: Elsevier Science B. V., IAAE XXIII Conference, Sacramento.

[24] Alemseged S., (2011) "Assessment of quality of haricot bean seed in Boricha Woreda, Sidama zone, SNNPRS", unpublished MSc thesis.

[25] Abrham M., (2011) "Participatory variety evaluation and selection of common bean to enhance capacity of Seed Producing Cooperatives in managing their variety portifolio" SNNPR, Etiopia" MA thesis.

[26] Mesfin Mulugeta, (2012). "Value chain and adoption intensity of improved haricot bean seed in Boricha woreda of SNNPR, Ethiopia".

[27] Million Kasaye, (2011). "Factors determining farmers' choice of improved quality seed and variety of haricot bean in Meskan and Boricha Woredas of SNNPR".

[28] Bikila Adugna (2012). "Assessment of Wheat Seed quality package in Wudiget and Amard Seed Producing Cooperatives in Sodo and Lanfero Woreda, SNNPRS" Unpublished MSc thesis.

[29] Shimels Araya, (2012). "Small holder adoption and market participation in improved local seed system": the case of Wheat seed in Meskan and Sodo Woreda, SNNPRS.

[30] Abebayehu G., (2011) "Technical efficiency analysis of haricot bean seed production in Boricha district, SNNRR, Ethiopia": Unpublished masters' thesis.

[31] Ligon E. (2008). Risk Management in the Cooperative Contract: Theory and evidence from village economies, The Review of Economic Studies 69 (1), 209-244.

[32] Dercon S. (2000) "Income risk, coping strategies and safety nets: Background paper, World Development Report 2000/01, Centre for the Study of African Economies, Oxford University.

[33] Arrow, K. J. (1971) "Essays in the Theory of Risk-Bearing" North-Holland, Amsterdam.

[34] Mailosi, M. (2011). "Crop Choices and Land Productivity on Rented Land in Northern Ethiopian Highlands". Norwegian University of Life Science.

[35] Rosenzweig, M. and H. Binswanger (1993), "Wealth, Weather Risk and the Composition and Profitability of Agricultural Investments", Economic Journal, vol.103, no.56-78

[36] Barry P. J., Baker C. B. (1984) "Risk Management in Agriculture", Iowa State University Press, Ames (1984), pp. 183-198.
[37] Richard C. and Mahen M. (2005): Causes of diversification in agriculture over time: Evidence from Norwegian farming sector: 'The Future of Rural Europe in the Global Agri-Food System', Copenhagen, Denmark.

[38] Carter, M. R. (1997) "Environment, technology, and the social articulation of risk in West African agriculture": Economic Development and Cultural Change, 45 (3) (1997), pp. $557-$ 590.

[39] Pandey, S., Behura, D. D., Villano, R., Naik D., (2001): Economic cost of drought and farmers' coping mechanisms: a study of rain fed rice systems in eastern India (Unpublished paper). IRRI, Los Baños.

[40] Upton, M. (1987) "African Farm Management" Cambridge University Press, Cambridge.

[41] Wik M. (2004). "Experimental Studies of Peasant's Attitudes towards Risk in Northern Zambia", Agricultural University of Norway.

[42] Pender, J. and Alemu D. (2007) Determinants of Smallholder Commercialization of Food Crops, Theory and Evidence from Ethiopia. IFPRI Discussion Paper 00745, International Food Policy Research Institute, Washington, DC, USA.

[43] Seid N. \& Holger S., (2011) "Impact of proximity to Urban Center on Crop Production Choice and Rural Income", Ethiopian Journal of Economics, vol. XX, 105-131.

[44] Kruseman, G., Ruben, R., \& Tesfay, G. (2006). "Village stratification for policy analysis: Multiple development domains in the Ethiopian highlands of Tigray", Strategies for sustainable land management in the East African highlands, pp 81-106 Washington, DC: International Food Policy Research Institute.

[45] Pender, J., Place, F. and Ehui, S. (2006) "Strategies for Sustainable Land Management in the East African Highlands", Washington, D. C.: International Food Policy Research Institute. DOI: 10.2499/0896297578.

[46] Bosch, D. J., Pease J. W. (2000), Economic risk and water quality protection in agriculture, Review of Agricultural Economics, 22 (2) pp. 438-463.

[47] Jose A. Gomez-Limon (2002): Agricultural Risk Aversion Revisited: A Multicriteria Decision-Making Approach, Paper prepared for presentation at the $\mathrm{X}^{\text {th }}$ EAAE Congress 'Exploring Diversity in the European Agri-Food System', Zaragoza (Spain), 28-31 August 2002.

[48] Wang J., R. Mendelsohn, A. Dinar, J. Huang (2010): How Chinese farmers change crop choice to adapt to climate change, Clim. Chang. Econ., 1, pp. 167-185.

[49] Klasen, S., J. Priebe, R. and Rudolf "Cash crop choice and income dynamics in rural areas: evidence for post-crisis Indonesia" Agric. Econ., 44 (2013), pp. 349-364 http://dx.doi.org/10.1111/agec.12015.

[50] Andrea B., (2014) "Crop choices under risk and subsistence constraints: evidence from rural Ethiopia.

[51] Lee M. J. (2005): Micro-Econometrics for Policy, Program and Treatment Effects. Advanced Texts in Econometrics. Oxford University Press.

[52] Wooldridge, J. M. (2010). "Econometric Analysis of CrossSection and Pannel Data. London, England": The MIT Press. 
[53] Lipton, M. (1968). "The Theory of Optimizing Peasant." Journal of Development Studies, 4:, 154-74.

[54] Yesuf, M. (2009). Poverty, "Risk Aversion, and Path Dependence in Low-Income Countries: Experimental Evidence from Ethiopia”. American Journal of Agricultural Economics, Vol. 91, Issue 4, pp. 1022-1037.

[55] Abebe Z. (2011), Dimensions and Determinants of Poverty among Rural Households: Unpublished MA thesis, Addis Ababa University, Ethiopia.
[56] Ayelech B., Konrad H. Humboldt, and Benedikt K. (2005), "Determinants of poverty in rural Ethiopia": Quarterly Journal of International Agriculture 44 (2005), No. 2: 101120.

[57] Collier, P. and J. W. Gunning (1999), "Explaining African Economic Performance", Journal of Economic Literature, March, vol. XXXVII, No.1, 64-111. 